\title{
宇宙溶接技術の研究開発
}

\section{Development of Space Welding Technology}

\author{
吹田義 - * \\ Yoshikazu SUITA
}

Key Words: Welding in Space, In-Space Welding, Space GHTA Welding, Space DL Welding, Weld Repair

\section{1.はじめに}

本誌 21 巻 2 号 (1995) 掲載の「宇宙への挑戦 - 宇宙アー ク溶接法の開発一」で、1995 年頃までの米国、旧ソ連 (ウクライナ) および我が国の宇宙溶接技術の状況と宇宙 GHTA (Gas Hollow Tungsten Arc) 溶接技術を紹介した。本稿 では、その後の宇宙溶接技術の動向と筆者らが開発をして いる宇宙 GHTA 溶接技術と宇宙 DL (Diode Laser) 溶接技術 の研究開発について紹介する。

\section{2. 宇宙溶接技術の動向}

旧ソ連は、1984 年にサリュート 7 号の船外で世界初の手 持ち多目的電子ビーム・ツール VHT (Versatile Hand Tool) を 使用した溶接・溶射実験を成功させ、1986 年にはミール 船外でヒンジを電子ビーム溶接で溶融・凝固させて長さ 12 $\mathrm{m}$ のトラス桁を製作した。このような実績から、旧ソ連は 宇宙溶接技術 ${ }^{1-4)}$ をほほ確立したと推察している。その後、 宇宙溶接技術はパトン電気溶接研究所のあるウクライナに 引き継がれている。一方、NASA は 10 年以上に亘って長 期運用される国際宇宙ステーション ISS (International Space Station) の修理に宇宙溶接技術が必要になることから、1997 年にパトン電気溶接研究所が開発した電子ビーム溶接装 置「ユニバーサル」を借り、スペース・シャトルのカーゴ ベイで宇宙溶接実験を行う計画をした。しかし、宇宙飛行 士の安全性確保やシャトル・スケジュールの問題で中止 ${ }^{5,6)}$ にした。その後、NASA は詳細不明であるが、EPL (Electric Propulsion Laboratory) 社が開発した高真空環境でも溶接可 能なアーク溶接ヘッド ${ }^{6}$ の評価試験を行っている。

ロシアは、NASAから送り返された「ユニバーサル」を 宇宙ステーション・ミールに打ち上げて船外活動 (EVA: Extra-Vehicular Activities) による宇宙溶接実験を計画したよ うである。しかし、ミールの老朽化と維持費の確保が困難 になり、ミールが廃棄されて宇宙溶接実験は行われなかっ
た。そのために、宇宙溶接技術開発が行き詰まった状況に ある。

我が国では、野城らが微小重力環境で GTA 溶接 ${ }^{7) 、}$ 、模 擬宇宙環境で電子ビーム溶接実験 ${ }^{8)}$ を行い、重力加速度が 溶接現象に及ぼす影響を調査している。正箱らはHCAの アーク柱および入熱特性を調査 ${ }^{9}$ している。著者らは真空 溶接装置を搭載した航空機の放物飛行で得られる模擬宇宙 環境において 2000 年に SUS304 ステンレス鋼管のメルトラ ン突合せ溶接実験 ${ }^{10)}$ を成功させた。また、2008 年にはア ルミニウム管の溶加ワイヤ供給突合せ溶接実験 ${ }^{11}$ を成功さ せて宇宙 GHTA 溶接技術をほほ確立した。現在は、日本の 宇宙実験施設 ISS「きぼう」の船外実験プラットホームや ISS に物資を搬入した後の HTVでの宇宙溶接実験を提案し、 宇宙 GHTA 溶接技術の実証実験の機会を待っている。また、 重要技術を開発する場合は、異なる原理の技術を平行して 開発する必要があるとの考えと近年の半導体レーザの高出 力化に注目して 2002 年に宇宙 DL (Diode Laser) 溶接法を提 案 ${ }^{12)}$ して研究開発を実施している。宇宙 DL 溶接技術につ いては、光学部品への金属蒸着防止技術 ${ }^{13)}$ を確立して模擬 宇宙環境での溶接実験の準備をしている。

一方、NASA では 2000 年頃から活発な動き ${ }^{14)}$ が見られる。 MSFC (Marshall Space Flight Center) では、シャトルの外部 燃料タンクへの摩擦擋拌接合 (FSW: Friction Stir Welding) の適用に続き、手持ち高速 FSW (HS-FSW) ユニットやロ ボット支援手持ち高速 FSW ユニットを開発している。そ して、回転ツールを必要としない超音波擋拌接合 (USW: Ultrasonic Stir Welding) ユニットの開発も行っている。また、 厚板の宇宙溶接を対象にした熱擋拌接合 (TSW: Thermal Stir Welding)の開発も実施している。この接合法は加熱、攪拌 および鍛造の過程を独立に制御できるのが特徵である。筆 者は、これらの擋拌接合は宇宙污染防止に有効な接合法に なると考えている。若い技術者・研究者に今後の技術開発 を期待したい。

*香川高等専門学校 創造工学専攻（７ 761-8058 香川県高松市勅使町 355）

Kagawa National College of Technology Advanced Course in Industrial and Systems Engineering (355 Chokushi-cho, Takamatsu, Kagawa 761-8058 Japan) 


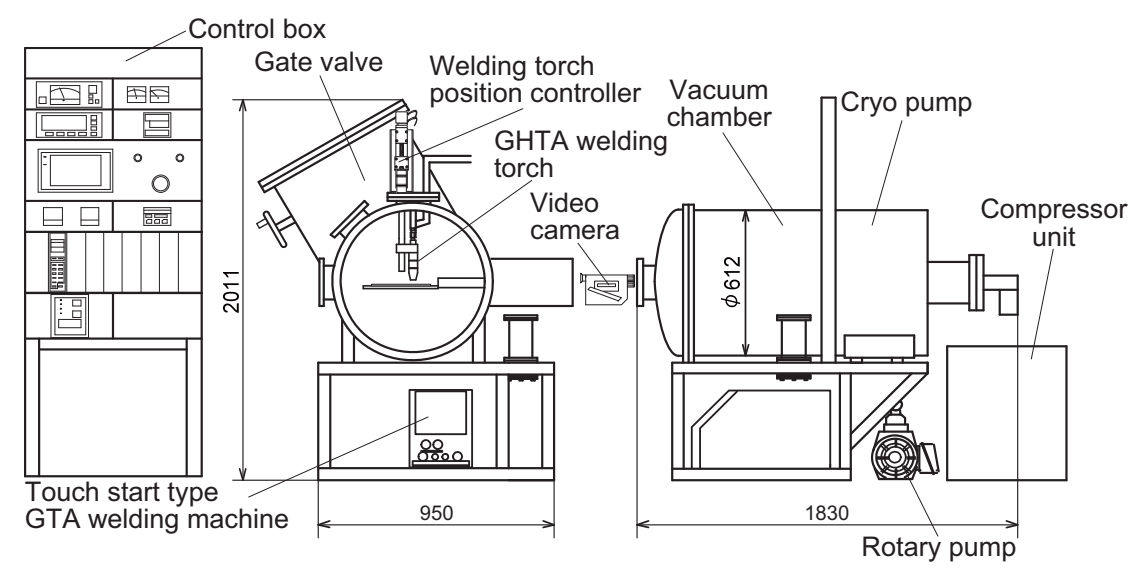

Fig.1 Space GHTA welding experiment system under ultrahigh-vacuum condition.

\section{3. 宇宙 GHTA 溶接技術の開発}

\section{1 宇宙 GHTA 溶接技術の開発経緯}

1992 年に宇宙 GHTA 溶接法を発表 ${ }^{15,16)}$ した後、地上真 空容器内と航空機を使用した模擬宇宙環境での溶接実験 を実施して、以下に述べる技術開発を行った。まず、溶接 起動直後に発生する過渡アーク放電によるコレット・ボ ディー溶損の課題は、酸化トリウム入り中空タングステン 電極に変えて電子放出能の優れる酸化ランタン入り中空夕 ングステン電極を採用することで解決した。そして、真空 環境下でSUS304 ステンレス鋼のメルトラン突合せ溶接、 溶加ワイヤ供給突合せ溶接実験によって溶接欠陥のない充 分な継手強度を有する突合せ溶接継手を製作できることを 実証 ${ }^{17,18)}$ した。

次に、航空機実験や ISS「きぼう」船外実験プラットホー ムでの宇宙溶接実験に備えて、ISS 軌道圧力での溶接実験 で高周波高電圧アーク起動 ${ }^{199}$ 、直流高電圧アーク起動 ${ }^{20)}$ 押 よびタッチスタート方式のアーク起動技術 ${ }^{21)}$ が適用でき ることを実証した。1997 年から 3 年間、宇宙開発事業団 NASDA（現在の宇宙航空研究開発機構 JAXA）の支援を受 けて、航空機 MU-300 を使用して模擬宇宙環境で SUS304 ステンレス鋼管のメルトラン突合せ溶接実験 ${ }^{10)}$ に成功した。 その後、アルミニウム合金の溶接に必要不可欠な溶接中 に母材表面の酸化膜を除去する技術の研究開発を行った。 その酸化膜除去技術を適用してアルミニウム合金の溶加ワ

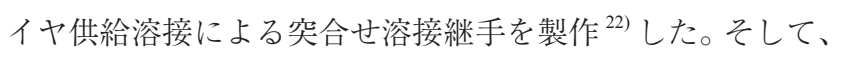
優れた溶接外観と強度を持つ突合せ溶接継手を製作できる ことを実証した。

地上での最終段階の実験として、宇宙環境でアルミニ ウム合金の溶接に宇宙 GHTA 溶接技術が適用できること を検証するために、宇宙航空研究開発機構 JAXA (Japan Aerospace Exploration Agency) の支援を受けて 2005、06 年 に航空機 G- II を使用した模擬宇宙環境でアルミニウム管の

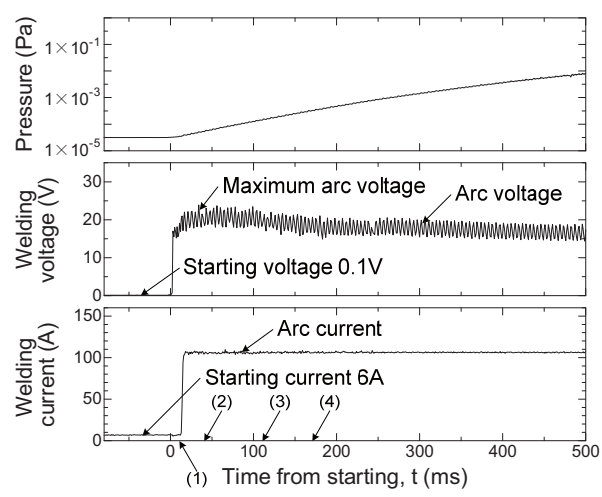

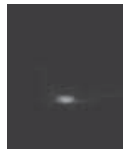

(1) $10 \mathrm{~ms}$

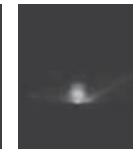

(2) $40 \mathrm{~ms}$

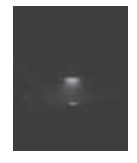

(3) $110 \mathrm{~ms}$

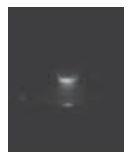

(4) $170 \mathrm{~ms}$

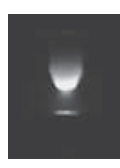

$1 \mathrm{~s}$
Fig.2 GHTA starting phenomenon in high-vacuum.

突合せ溶接実験 11,23 を成功させた。以下に、地上真空容器 内の実験と航空機を使用した模擬宇宙環境での溶接実験に ついて紹介する。

\section{2 地上真空容器内での溶接実験}

3.2.1 ISS 軌道圧力でのアーク起動と溶接実験

これまでの溶接実験は地上真空容器内圧力 $10^{-2} \mathrm{~Pa}$ で実 施した。そのために、ISS 軌道圧力 $10^{-5} \mathrm{~Pa}$ の高真空で宇宙 GHTA 溶接法が適用できるかどうか不安があった。そこで、 $\mathrm{Ar}$ 排気速度 $8.4 \mathrm{~m}^{3} / \mathrm{s}$ のクライオポンプを採用した Fig.1の 高真空環境溶接実験システムを製作して溶接起動実験を実 施した。高周波高電圧、直流高電圧およびタッチスタート の起動方式を検討したが、どの起動方式でも $10^{-5} \mathrm{~Pa}$ でアー ク起動と溶接が可能であった。しかし、高周波高電圧方式 には電磁ノイズ障害、直流高電圧方式にはグロー放電に移 
行する問題がある。また、同時に両方式は高電圧を使用す るので安全上にも問題がある。それに対して、母材に接触 させた中空タングステン電極を引き上げて溶接を開始する タッチスタート方式は、それらの課題を解決でき、しか も起動から約 $10 \mathrm{~ms}$ 後に設定溶接電流に到達する安定した アーク溶接起動が可能になる。Fig.2は母材に A2014-T6を 用い、Fig.1の溶接実験システムを使用した高真空 $10^{-5} \mathrm{~Pa}$ でのタッチスタート方式のアーク起動状況 ${ }^{21)}$ である。溶接 電流 $100 \mathrm{~A} 、 \mathrm{Ar}$ ガス流量 $1.67 \mathrm{ml} / \mathrm{s}$ 、電極間隔 $3 \mathrm{~mm}$ で、起 動後の放電状況、電流、電圧および圧力の時間変化を示し ている。タッチスタート方式の溶接起動では、直流高電圧 方式のようにグロー放電に移行する現象はなく、全てアー ク放電に移行する安定したアーク起動が可能である。また、 電極引き上げ条件、環境圧力、母材の種類などの影響を受 け難く、電極の損耗もほとんどなく、数 $10 \mathrm{~ms}$ で設定した 溶接電流 $100 \mathrm{~A}$ に到達できるなど宇宙溶接に適したアーク

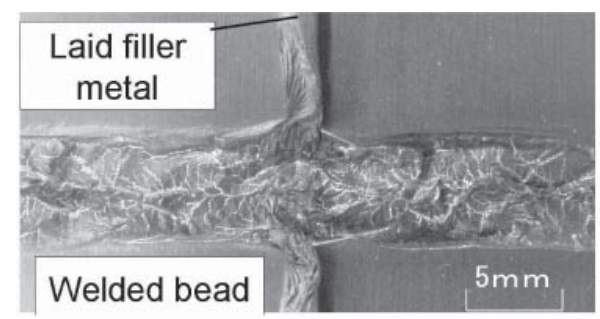

(a)DC-constant current

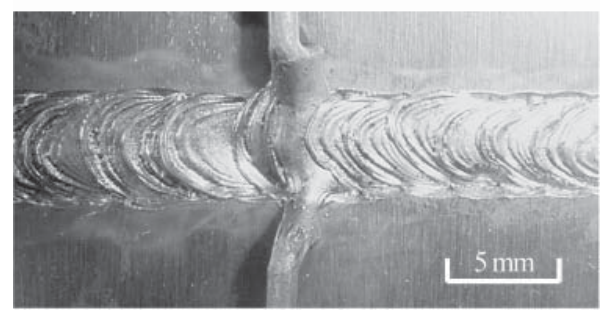

(b) DC-pulsed current

Fig.3 Bead appearance by space GHTA welding process in vacuum.
起動方式である。宇宙 GHTA 溶接法は、絶縁破壊のために 中空タングステン電極先端から微量の Ar ガスを流出させ るので、アーク起動と同時に真空容器内の圧力が急上昇す るが、約 $80 \mathrm{~ms}$ の期間は ISS 軌道圧力 $10^{-5} \mathrm{~Pa}$ の範囲にあり、 その期間でもアーク放電が維持できることを検証 ${ }^{21)}$ できた。 3.2 .2 酸化膜除去技術

2000 系などの熱処理型アルミニウム合金表面には、人工 時効で発生した厚さ $70 \sim 200 \mathrm{~nm}$ の酸化皮膜 $\mathrm{Al}_{2} \mathrm{O}_{3}$ が形成 されている。このような材料を DCEN（直流電極マイナス） 極性で溶接すると高融点の酸化膜が溶融せずに、酸化膜下 の母材のみが溶融する現象 ${ }^{24,25)}$ が発生する。そのために、 溶融金属の流動性が悪く、メルトラン突合せ溶接ではのど 厚不足の溶接金属になる。また、溶加ワイヤ供給溶接では、 溶融池に溶加ワイヤを供給するのが難しくなり、融合不良 の原因になる。従って、溶接中に酸化膜を除去する必要が ある。種々の酸化膜除去技術 ${ }^{26)}$ があるが、クリーニング作 用を利用するために交流溶接電源を使用すると電極プラス 期間にアークが消失する現象 ${ }^{25)}$ が発生して、酸化膜を除去 できない。また、再点弧電圧を高くすると㓌極点が母材表 面を高速移動する現象が発生して溶接が困難になる。宇宙 GHTA 溶接法は、GTA 溶接を基礎にした溶接技術であるの で交流溶接電源を使用したクリーニング作用を利用する工 夫が必要である。酸化膜除去の課題は、パルス溶接電源を 使用する DCEN 極性の溶接で解決できた。ベース電流から パルス電流に移行するときのアーク衝撃圧力（短時間での アークプラズマ気流の運動量の変化に起因する圧力) で酸 化膜を機械的に粉砕除去する技術である。Fig.3は母材表 面に溶加ワイヤを置いて、それを横切るようにメルトラン 溶接した場合の溶接金属外観である。Fig.3(a)の直流定電 流を使用した場合は、酸化膜を除去できないので溶加ワイ ヤと溶接金属の融合状況が悪い。一方、Fig.3(b)のように 直流パルス電流を使用した場合は、溶加ワイヤと溶接金属 が融合しており、溶加ワイヤ供給溶接が可能なことがわか る。この直流パルス電流による酸化膜除去技術は、低圧環
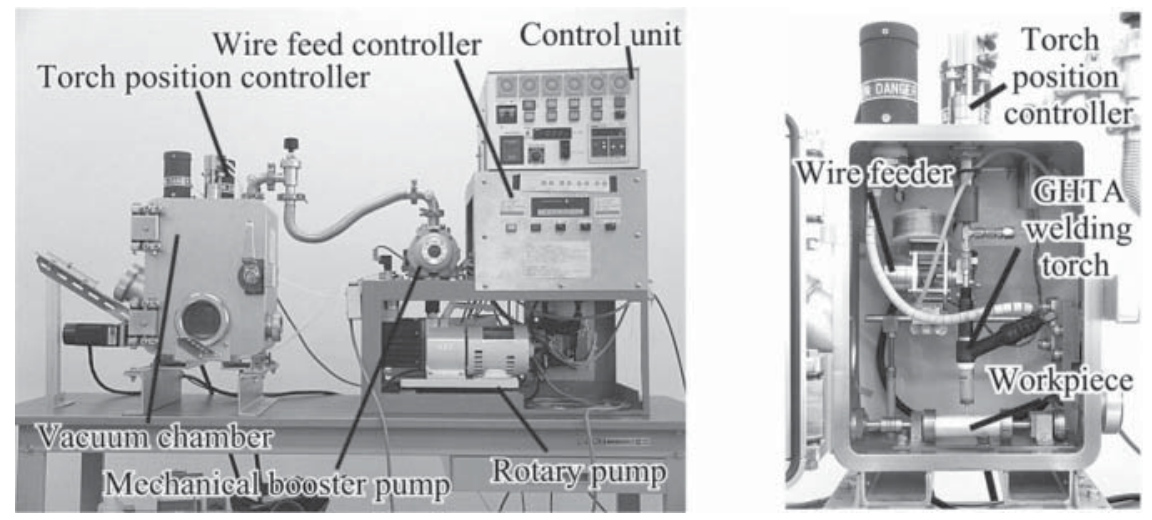

Fig.4 Experiment system for space GHTA welding process under simulated space environment. 
Table 1 Effects of gravity on arc discharge and weld bead shape.
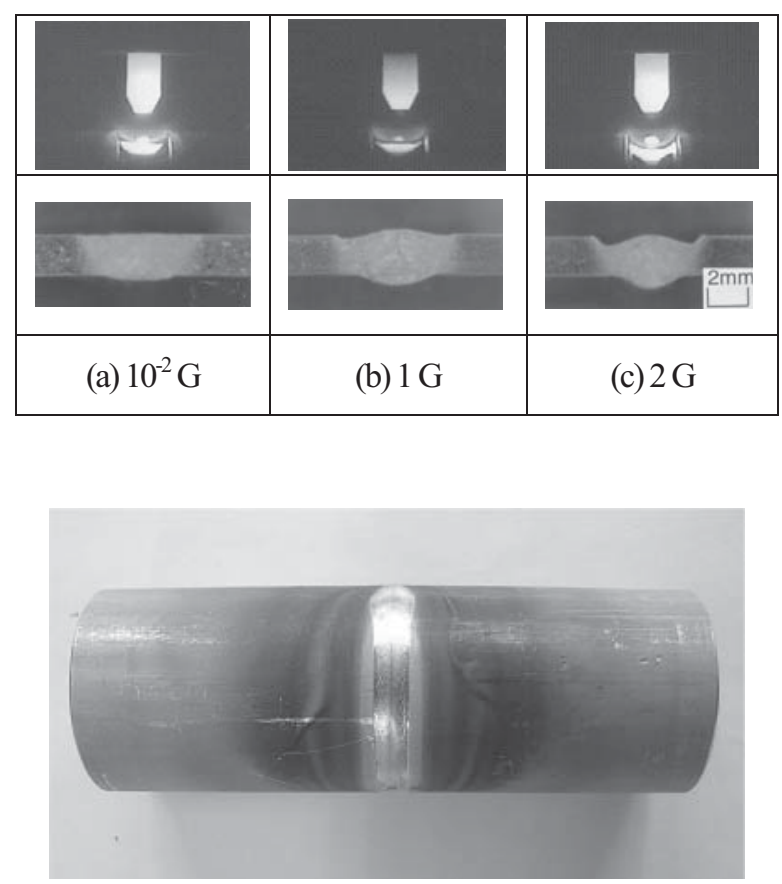

Fig.5 Bead appearance of butt welded stainless steel pipe by space GHTA welding process under simulated space environment.

境で有効であって、大気圧環境では適用できない。

\section{3 模擬宇宙環境での溶接実験}

\subsubsection{SUS304 鋼管のメルトラン溶接実験}

小型ジェット機 MU-300 の放物飛行で得られる微小重力 環境を利用した模擬宇宙環境で宇宙 GHTA 溶接実験を行う ために Fig.4 に示す航空機搭載型模擬宇宙環境溶接実験シ ステムを製作した。MU-300の供給電力では溶接電力が不 足するのでバッテリー溶接電源を採用した。アーク起動方 式は直流高電圧方式とした。Fig.4のように真空容器内の 下部にSUS304 ステンレス鋼管（外径 $30 \mathrm{~mm}$ 、肉厚 $2 \mathrm{~mm}$ ) を水平に設置し、鋼管を回転させながら鋼管頂部で周方向 に $20 \mathrm{~s}$ 間の模擬宇宙環境で、メルトラン溶接でビード溶接 と突合せ溶接実験を行った。溶接条件は、DCEN 極性で直 流電流 $90 \mathrm{~A}$ 、溶接速度（鋼管表面の周速度） $2.4 \mathrm{~mm} / \mathrm{s} 、 \mathrm{Ar}$ ガス流量 $1.33 \mathrm{ml} / \mathrm{s}$ である。先端を $60^{\circ}$ 円錐台状に成形した 外径 $4 \mathrm{~mm}$ 、内径 $1.8 \mathrm{~mm}$ の $2 \%$ 酸化ランタン入りタングス テン電極を使用し、電極高さは $3 \mathrm{~mm}$ とした。

Table 1 は $10^{-2} \mathrm{G}$ 微小重力、地上 $1 \mathrm{G}$ 重力㧍よび $2 \mathrm{G}$ 過重 力環境での溶接状況である。1 $10^{-2} \mathrm{G}$ 微小重力、 $2 \mathrm{G}$ 過重力環 境の溶接は航空機の放物飛行で実現し、1 G 重力環境での 溶接は駐機場で行った。電磁力の影響を大きく受けるアー ク放電現象には、重力加速度の影響が現れないことを確認 した。そのために、溶込み深さ、溶接ビード幅には重力加 速度の影響があまり認められない。しかし、Table 1のよ

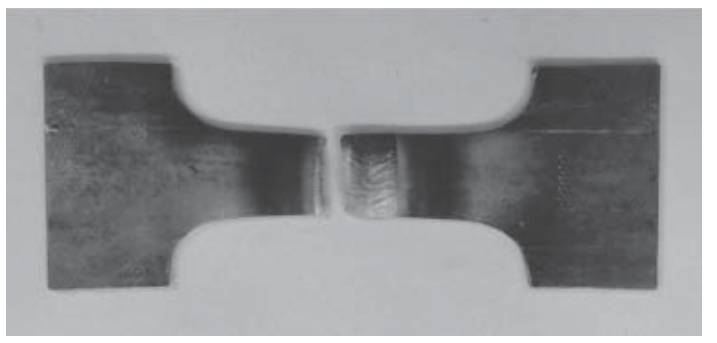

Fig.6 Tensile test specimen of stainless steel pipe welded using space GHTA welding process under simulated space environment.

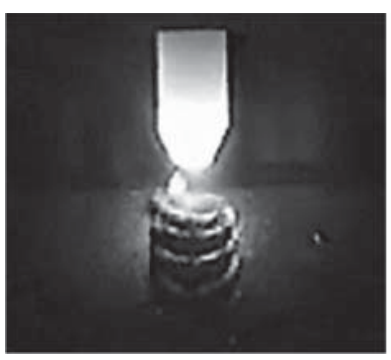

(a) Front view

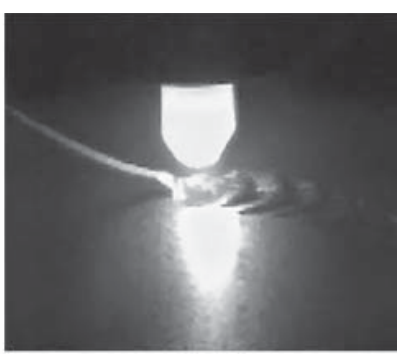

(b) Upper side view
Fig.7 Space GHTA welding aluminum pipe with wire feed under simulated space environment.

うに溶接金属形状には明らかに重力加速度の影響が認めら れ、重力加速度が大きいほど溶接金属が管中心方向に垂れ 下がる現象が確認できた。

Fig.5 はメルトラン溶接で製作された SUS304 ステンレス 鋼管突合せ溶接継手の外観写真である。模擬宇宙環境の溶 接実験で溶接欠陥のない優れた溶接ビード外観の溶接継手 が製作できた。また、透過 X線検査でもブローホール、融 合不良などの溶接欠陥は確認できなかった。その継手から 引張試験片を採取して引張試験を行った結果を Fig.6 に示 す。破断部は溶接部外側の熱影響部であり、母材強度以上 の継手強度が得られた。これらの実験結果は、模擬宇宙環 境でも宇宙 GHTA 溶接のメルトラン溶接で優れた突合せ溶

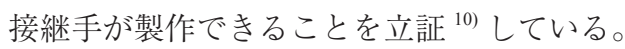

3.3.2 アルミニウム管の溶加ワイヤ供給溶接実験

直流パルス電流による酸化膜除去技術を確立し、地上真 空容器内でアルミニウム合金の溶加ワイヤ供給溶接で溶接 欠陥のない充分な継手強度を有する突合せ溶接継手の製作 に成功 ${ }^{22}$ した。その宇宙 GHTA 溶接技術が宇宙空間で適用 できることを確認するために 2005、06 年にジェット機 GII を使用して A1070TD-H14 アルミニウム管（直径 $30 \mathrm{~mm}$ 、 肉厚 $2 \mathrm{~mm}$ ）の模擬宇宙溶接実験を行った。航空機から供 給される電力を $200 \mathrm{~V}$ に昇圧して、市販の直流パルス GTA 溶接機（タッチスタート方式）を使用した。溶接条件はパ ルス電流 $140 \mathrm{~A}$ 、ベース電流 $20 \mathrm{~A}$ 、パルス周波数 $3.5 \mathrm{~Hz}$ 、 パルス幅 $30 \%$ 、溶接速度（アルミニウム管周速度） $7 \mathrm{~mm} / \mathrm{s}$ 


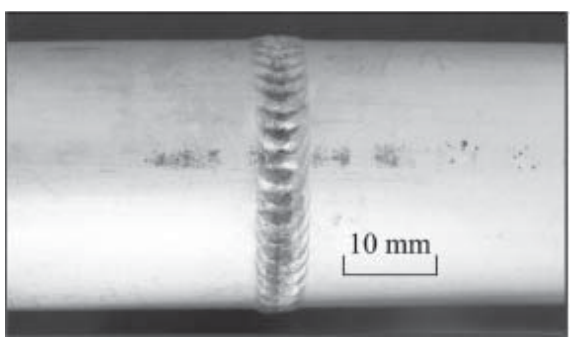

Fig.8 Bead appearance of butt welded aluminum pipe by space GHTA welding process under simulated space environment.

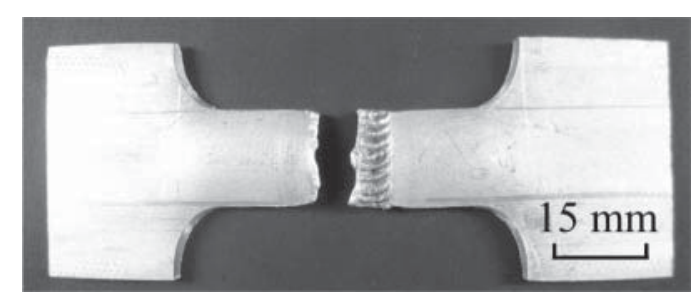

Fig.9 Tensile test specimen of aluminum pipe welded using space GHTA welding process under simulated space environment.

である。電極材質、電極高さおよび Ar ガス流量は SUS304 ステンレス鋼の溶接実験と同条件である。直径 $1 \mathrm{~mm}$ の溶 加ワイヤA4043を供給速度 $12.5 \mathrm{~mm} / \mathrm{s}$ で溶融池前縁に供給 した。

Fig.7は模擬宇宙環境で溶加ワイヤを供給しながら突合 せ溶接を行っている状況である。適切な溶加ワイヤ供給条 件であれば、パルス電流で酸化膜を除去しながらスパッタ 発生のない溶接ができることが実証できた。しかし、ワイ ヤ供給速度が速すぎるとアークによって切断された溶加ワ イヤが浮遊飛散する現象が発生することを確認した。従っ て、溶加ワイヤ供給溶接では供給条件を慎重に選定する必 要がある。

Fig.8 は、模擬宇宙環境下で直流パルス電流を使用した溶 加ワイヤ供給溶接で得られたアルミニウム管の突合せ溶接 継手である。溶接欠陥のない優れた溶接ビード外観の溶接 継手を製作できた。この突合せ溶接継手から引張試験片を 採取して引張試験を行った。その結果は、Fig.9に示すよ うに母材熱影響部の軟化域で破断し、充分な継手強度が得 られることを検証できた。以上の実験から、宇宙 GHTA 溶

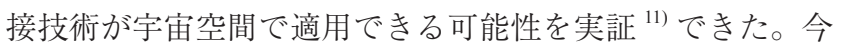
後は、NASAよりも先にISS の日本宇宙実験施設「きぼう」 船外実験プラットホーム（曝露部）あるいは ISS に物資を 搬入後の HTV 船内与圧部・非与圧部での宇宙溶接実験が 望まれる。

\section{4. 宇宙 DL 溶接技術の開発}

1991 年に米国において航空機を使用した模擬宇宙環境下
でNd-YAG レーザ溶接実験 ${ }^{27)}$ が行われた。しかし、大型・ 重量で発振効率が低いなどの問題があった。宇宙空間での レーザ溶接を実現するために、太陽光励起レーザ溶接の概 念が提案されている。一方、1990 年代後半になると高出 力半導体レーザが開発されるようになった。高変換効率で ファイバー伝送が可能なこと、レーザ光は真空環境でも熱 源として利用できることに着目して、著者は宇宙 DL (Diode Laser) 溶接技術を提案 ${ }^{12)}$ した。ISS などの与圧部にレーザ 発振装置を設置して、レーザ光をファイバーで伝送して溶 接を行うシステムである。その可能性を検証するために、 地上真空容器内で各種の溶接実験を実施した。そして、宇 宙 DL 溶接が宇宙で適用できる可能性が高いことを確認し た。最近のファイバーレーザの開発動向やその特長を考え るとファイバーレーザ溶接の宇宙適用も有望である。若い 技術者・研究者の活躍の場になると思う。

\section{1 宇宙 DL 溶接システムの構成と特徴}

宇宙で利用される宇宙 DL 溶接システムは、与圧部内に 設置されるレーザ発振装置、レーザ光伝送システム、宇宙 ロボットおよびレーザ溶接ヘッドで構成されると予想して いる。宇宙空間の溶接では金属蒸気による周辺機器（天体. 地球観測機器、通信機器など）の污染が問題になる。その ために、溶接作業は基本的には特設溶接作業場や宇宙格納 庫で行われる。宇宙ステーション、宇宙輸送システムなど の予圧部内に設置したレーザ発振装置からレーザ光を宇宙 ロボットが把持するレーザ溶接へッドに伝送して、自動溶 接を行うシステムである。また、与圧部内の宇宙飛行士が モニターを見ながらマニピュレータ先端に取り付けたレー ザ溶接ヘッドで溶接する作業も考えられる。デブリ衝突な どの不測の事態に対しては、溶接技能を有する宇宙飛行士 が船外活動 EVA としてレーザ溶接ヘッドを手に持って修理 溶接を行う場合も想定される。

宇宙 DL 溶接システムは、次のような特徵を持っている。

1) 軽量 - 小型で発振効率が高い（将来的には、太陽光励起 技術の適用も予想される)

2) ファイバー伝送が可能なために自由度が大きく、宇宙ロ ボットやマニピュレータとのシステム構築が容易

3）与圧部内での溶接作業にも対応できる

4）スパッタが少なく安全であるが、アルミニウム合金の溶 接では反射光対策が必要

5）シールドガスなど光学部品の金属蒸着防止対策が必要

本稿では環境圧力が溶接状況、溶接金属の寸法・形状に 及ぼす影響と金属蒸着防止技術について述べる。

\section{2 地上真空容器内での DL 溶接実験}

大型クライオポンプ ( $\mathrm{Ar}$ 換算排気速度 $\left.8.4 \mathrm{~m}^{3} / \mathrm{s}\right)$ を採用 した ISS 軌道圧力 $10^{-5} \mathrm{~Pa}$ を実現できる Fig.10の高真空環境 半導体レーザ溶接実験システムを使用した溶接実験結果を 紹介する。DL 溶接装置は、混合波長（940、808） $\pm 10 \mathrm{~nm}$ 


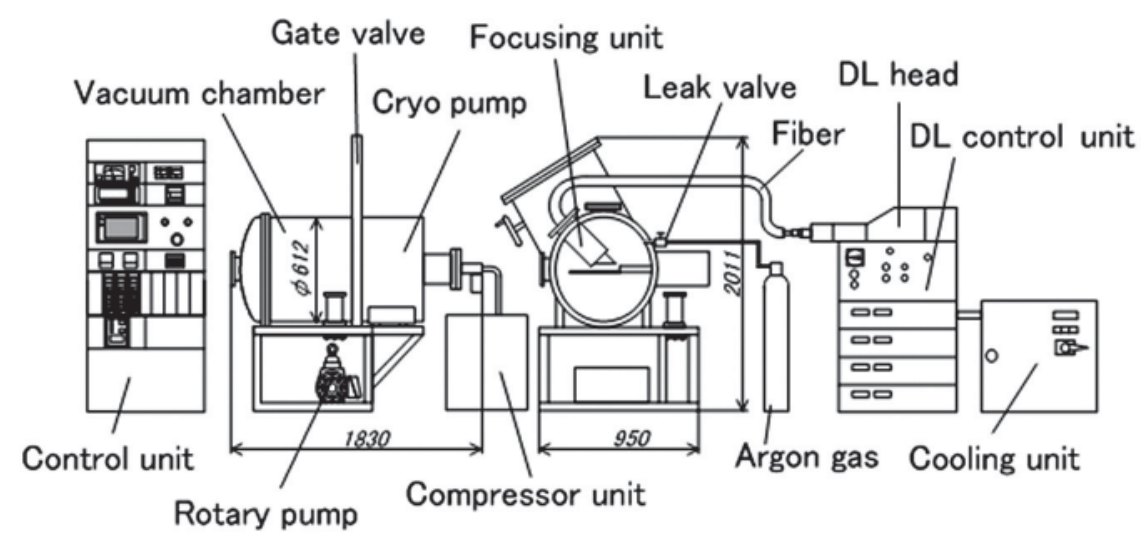

Fig.10 High-vacuum DL welding experiment system.

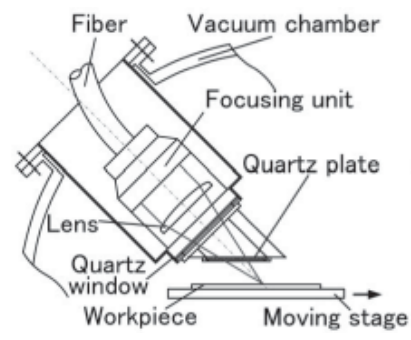

(a) Nozzleless unit

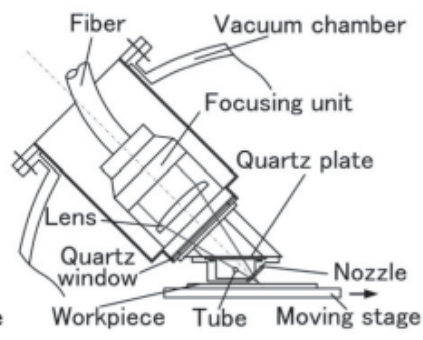

(b) Nozzle-equipped unit

Fig.11 Focusing unit.

で $2.5 \mathrm{~kW}$ 連続発振ダイレクト・ダイオードレーザである。 $\mathrm{DL}$ ヘッドから約 $2 \mathrm{~kW}$ のレーザ光をコア径 $1.5 \mathrm{~mm}$ の光ファ イバーで真空容器外側に取り付けた射出ユニットに伝送し て、レーザ鉛直照射溶接とレーザ斜め照射溶接実験を実施 した。レーザ鉛直照射溶接では ISS 軌道圧力でもレーザ溶 接が可能であることを実証 ${ }^{12,28)}$ した。しかし、溶接中に発 生する金属蒸気で光学部品に金属蒸着が起こり、透過率の 低下と劣化・損傷が発生する問題を提示し、光学部品の金 属蒸着防止技術の確立の必要性を述べた。

レーザ斜め照射溶接実験 ${ }^{28)}$ では、Fig.11(a)のノズル無 射出ユニットからレーザを斜め照射してレーザ導入悹と保 護用石英板を通して、真空容器内の移動台車上の供試材 SUS304 ステンレス鋼をビード・オン・プレート溶接した。 供試材に照射されたレーザパワー実測值は約 $1.7 \mathrm{~kW}$ であ る。供試材表面でのレーザ光スポット形状は短径約 $3 \mathrm{~mm}$ 、 長径約 $4 \mathrm{~mm}$ の楕円である。真空容器内を $10^{-5} \mathrm{~Pa}$ まで排気 した後、リークバルブから Ar ガスを導入して所定の環境 圧力にして溶接した。板厚 $3 \mathrm{~mm}$ のSUS304 ステンレス鋼 を溶接速度 $0.2 \mathrm{~cm} / \mathrm{s}$ で後進溶接（レーザ照射方向と逆方向 にメルトラン溶接）した。

Table 2 は、環境圧力を変化させて溶接した結果である。 圧力 $10^{5} \mathrm{~Pa}$ と $10^{3} \mathrm{~Pa}$ での溶接は、ほぼ同じで安定した溶接
Table 2 Effect of environment pressure on weld metal shape.

\begin{tabular}{|c|c|c|c|c|}
\hline \multicolumn{5}{|c|}{ Pressure, $\mathrm{P}(\mathrm{Pa})$} \\
\hline $10^{5}$ & $10^{3}$ & 10 & $10^{-2}$ & $10^{-5}$ \\
\hline & & & & \\
\hline & & & & \\
\hline & & & & \\
\hline
\end{tabular}

状況が観察され、供試材裏面まで溶融する溶接金属が得ら れた。溶接中に発生するレーザ誘起プルームで保護用石英 板が少し污染された。一方、環境圧力が $10 \sim 10^{-5} \mathrm{~Pa}$ の溶 接では、金属蒸気の蒸発が激しくなり、金属蒸気が高速で 拡散して保護用石英板や周辺機器に付着する金属蒸着現象 が顕著になる。金属蒸着が起きると保護用石英板のレーザ 光透過部（Table 3 参照）では、蒸着金属がレーザ光を吸 収して赤熱し、金属の蒸発と蒸着が繰り返される。そのた めに、レーザ光透過部が劣化して透過率が低下するので供 試材に照射されるレーザパワーが減少する。また、低圧環 境では蒸発反力が低下するので、Table 2 のように熱伝導 型溶融による溶込みの浅い溶接金属になる。前進溶接も、 後進溶接とほぼ同じ溶接現象、溶接金属形状が観察された。

実験の結果から $10 \mathrm{~Pa}$ 以下では、金属蒸気による保護用 石英板や周辺機器の污染が問題になることがわかった。そ こで、金属蒸着技術を確立するために保護用石英板の金 属蒸着膜厚を計測して蒸発金属の放射分布特性を調べた。 Fig.12 はその膜厚測定結果で、斜め照射のレーザ溶接でも 蒸発金属放射分布は溶融池表面を微小平面蒸発源と仮定し た図中の実線で示す余弦法則 (球状分布) ${ }^{29)} に$ 従うことが わかった。

4.3 光学部品の金属蒸着防止技術の開発

低圧環境の溶接では、前節で述べたように金属蒸着現象 
が問題になる。保護用石英板などの光学部品に蒸着した金 属蒸着膜は、レーザ光を吸収して発熱するので、光学部品 の透過率を低下させ、溶融・損傷 ${ }^{28)}$ させる原因になる。そ のために、宇宙 DL 溶接技術を宇宙適用するためには金属 蒸着防止技術の確立が必要になる。まず、レーザ斜め照

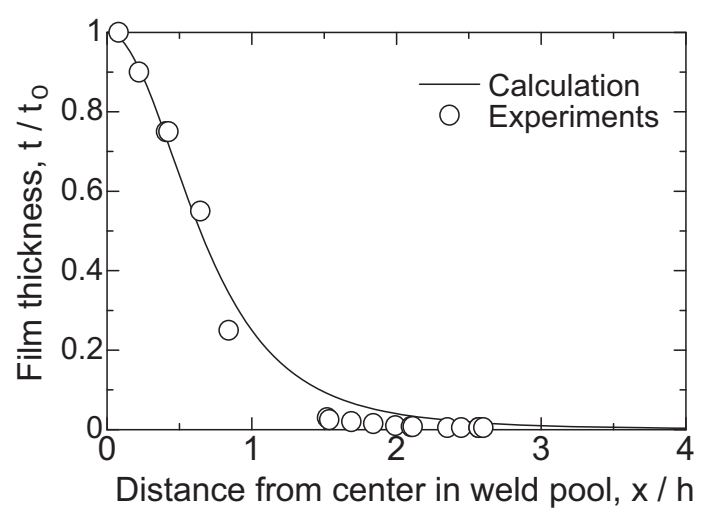

Fig.12 Film thickness distribution on protection quartz plate.

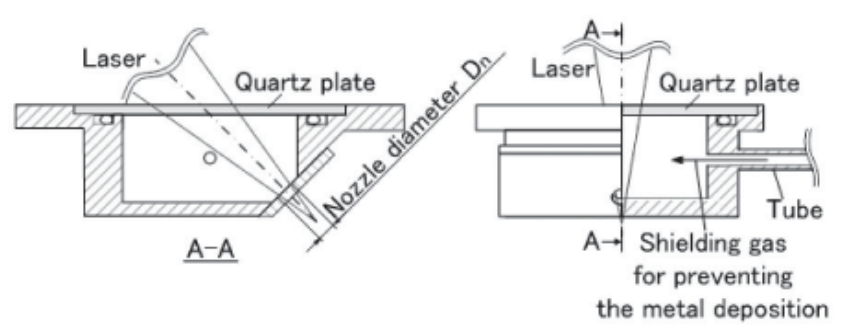

Fig.13 Nozzle detail.
射溶接の蒸発金属放射分布が余弦法則に従い、斜め方向の 金属蒸気が少ないことに着目した。ノズル付射出ユニット を採用してFig.11(b)のように保護用石英板をノズルで被 い、ノズルによる金属蒸気の遮蔽効果を調べた。その結果 は、ノズル口から金属蒸気が侵入して金属蒸着を防止でき なかった。次に、Fig.13のノズル詳細図に示すようにノズ ルに Ar ガスを供給してノズル口から Ar ガスを噴出させる 方法を検討した。Table 3 はAr ガスをノズルロから噴出さ せた場合と、溶接部から離れたリークバルブから真空容器 に導入して溶接した場合の保護用石英板の金属蒸着状況と 溶接金属の寸法・形状の関係である。円形の保護用石英板 の中央付近の黑く変色した領域が金属蒸着膜である。中心 付近の透明な楕円部がレーザ光透過部、その外側が金属蒸 着領域である。金属蒸着が発生するとレーザ光透過部で金 属蒸着膜の蒸発と蒸着が繰り返される。その結果、石英板 が劣化して透過率の低下、部分的な表面溶融㧍よびき裂が 発生する。Table 3 からわかるようにノズルから Ar ガスを 噴出させる場合は、 $\mathrm{Ar}$ ガス流量が $0.83 \mathrm{ml} / \mathrm{s}$ 以上になると 保護用石英板の金属蒸着を防止 $\left.{ }^{13}\right)$ できる。その結果、透過 率の低下がなく供試材に照射されるレーザパワーも低下し ないので溶込み深さの大きい溶接金属になる。Fig.14は、 溶接後の保護用石英板の透過率低下量と Ar ガス流量の関 係である。ノズルから Ar ガスを噴出させる場合は、 Ar ガ 久流量が $0.83 \mathrm{ml} / \mathrm{s}$ 以上になると保護用石英板の金属蒸着を 防止でき、透過率の低下を防ぐことができる。ノズル口径 $8 \mathrm{~mm}$ のノズルに流量 $0.83 \mathrm{ml} / \mathrm{s}$ の $\mathrm{Ar}$ ガスを供給した場合の ノズル内の推定 $\mathrm{Ar}$ ガス圧力は $16.9 \mathrm{~Pa}$ である。従って、ノ ズル内の $\mathrm{Ar}$ ガス圧力を $16.9 \mathrm{~Pa}$ 以上にすることで光学部品

Table 3 Effects of Argon flow rate on metal deposition on quartz plate and weld metal dimensions.

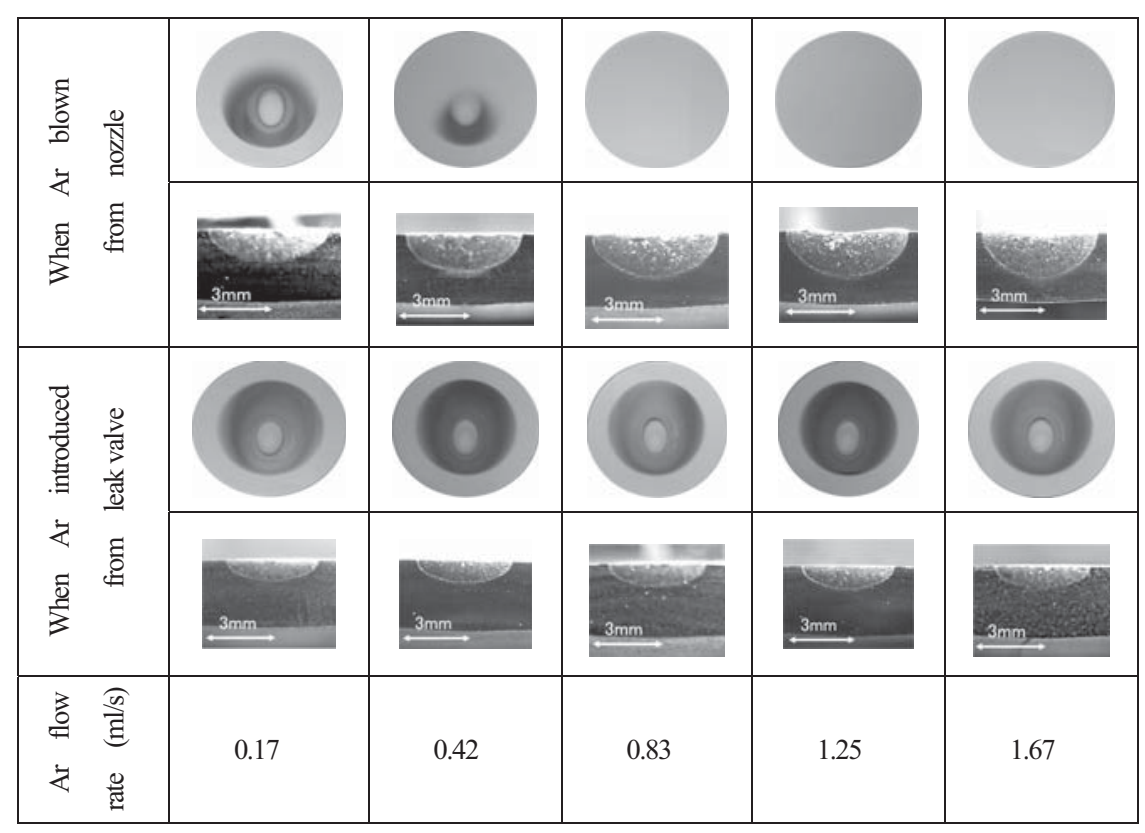




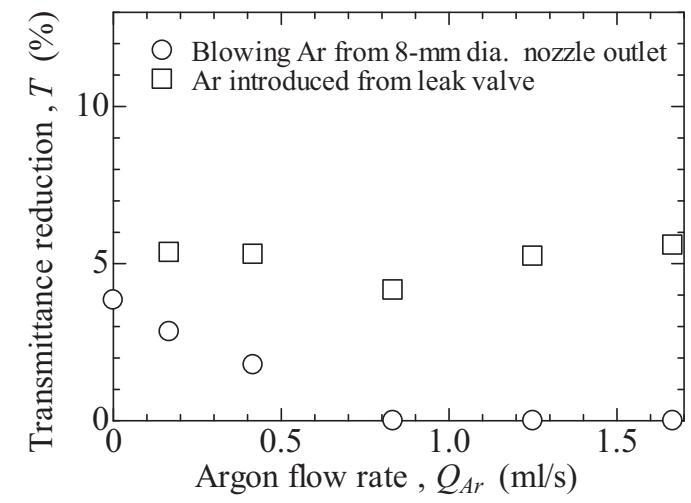

Fig.14 Effect of Argon flow rate on transmittance reduction in protection quartz glass.

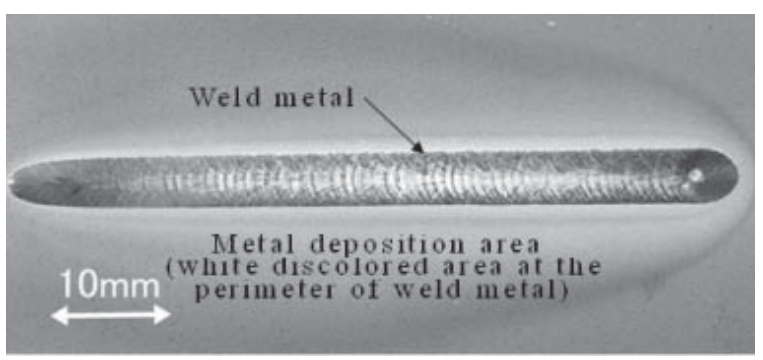

Fig.15 Metal deposition area around weld metal.

の金属蒸着を防止できることになる。

圧力が高くなると金属蒸着が発生し難くなる現象が知ら れている。ノズルから Ar ガスを噴出させた場合の効果を 調べるために、同じ Ar ガス流量をリークバルブから導入 して容器内圧力を同じにして溶接実験を行った。その結果、 リークバルブから Ar ガスを導入した場合は金属蒸着を抑 制できないことがわかった。Table 3 のように Ar ガス流量 $1.67 \mathrm{ml} / \mathrm{s}$ でも金属蒸着を抑制・防止できず、透過率が低下 して供試材に照射されるレーザパワーが低下するので溶达 みの浅い溶接金属になる。Fig.14の透過率低下量の結果も、 リークバルブから Ar ガスを導入した場合は透過率低下を 抑制できないことを示している。

開発した金属蒸着防止技術 ${ }^{13)}$ を適用して、Ar ガス流量 $0.83 \mathrm{ml} / \mathrm{s}$ 、溶接速度 $2 \mathrm{~mm} / \mathrm{s}$ でステンレス鋼板をメルトラン 溶接したときの溶接ビード外観を Fig.15に示す。溶接欠陥 のない、優れた溶接金属が得られる。 $\mathrm{Ar}$ ガスで押し戻され た金属蒸気が溶接金属周辺に付着している状況が確認でき る。このノズルで光学部品を蔽いノズルロから、Ar ガスを 噴出させる金属蒸着防止技術は、合計積算溶接時間 $1.5 \mathrm{hr}$ 問題が発生しないことを確認している。またこの金属蒸着 防止技術を適用して、ISS 軌道圧力に相当する高真空環境 で直径 $0.6 \mathrm{~mm}$ の溶加ワイヤ (Y308-WY) を供給しながら板 厚 $3 \mathrm{~mm}$ のSUS304 ステンレス鋼板の突合せ溶接継手を製
作して、引張試験を行った。その結果、ISS 軌道圧力に相 当する高真空環境でも宇宙 DL 溶接技術で充分に満足でき る溶接外観と機械的性質を有する突合せ溶接継手が製作で

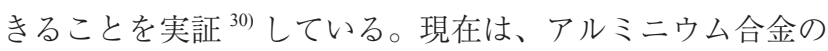
突合せ溶接継手、隅肉溶接継手の製作実験を実施している。

\section{5. まとめ}

本稿では、宇宙溶接技術の現状について紹介した。次に、 筆者等が研究開発している宇宙 GHTA 溶接技術と宇宙 DL 溶接技術の現状を紹介した。宇宙 GHTA 溶接技術について は、模擬宇宙環境で溶接欠陥のない突合せ溶接継手が製作 できることを実証した。地上での溶接実験を完了して、ISS およびHTVでの宇宙溶接実験の機会に備えた準備をして いる。宇宙 DL 溶接技術については、光学部品の金属蒸着 防止技術を確立して、次の段階である模擬宇宙環境での溶 接実験の機会を待っている。

\section{謝 辞}

1989 年に米国マサチューセッツ工科大学 (MIT: Massachusetts Institute of Technology）船舶工学科増渕興一教 授にMIT 客員研究員（文部省在外研究員）として受け入 れていただいた。増渕興一教授の助言から宇宙溶接に興味 を持つようになり、MIT では水中溶接の研究をしながら宇 宙溶接技術関連の情報収集・文献調査を行った。帰国後、 1991 年から高松工業高等専門学校（現在の香川高等専門学 校）の卒業研究、特別研究として学生諸君の協力を得て宇 宙溶接技術の研究開発を行うことができた。優れた創造力、 解析力および実行力を発揮して研究開発を進展させた多く の学生諸君にお礼を申し上げる。

最後に、研究の一部は、独立行政法人宇宙航空研究開発 機構の支援を受け、財団法人日本宇宙フォーラムが推進し ている「宇宙環境利用に関する地上研究公募」プロジェク トの一環として行ったものであること記してお礼を申し上 げる。

\section{引用文献}

1) B. E. Paton: WELDING IN SPACE, Welding Engineer, 57-1(1972), pp. 25-29.

2) B. E. Paton: STATE-OF-ART AND PROSPECTS OF DEVELOPMENT OF AEROSPACE ENGINEERING IN THE USSR, Proc. "Welding in Space and the Construction of Space Vehicles by welding", September、24-26(1991), New Carrollton, Maryland, USA, pp. 1-11.

3) V. A. Dzhanibekov, A. A. Zagrebelny, S. S. Gavrish, V. V. Stesin, V. D. Sheleyagin, N. N. Yurchenko, A. V. Markov: Welding Equipment for Space Applications, Ibid. pp. 49-58.

4) 黄地尚義訳: 宇宙の溶接、産報出版 (2000), B. E. Paton、 V. F. Lapchinsky: WELDING in SPACE and RELATED TECHNOLOGIES、pp.35-98. 
5) Mary Ruth Johnsen: Space Welding Experiment Postponed Indefinitely, Welding Journal, 76, 4(1997), p.22.

6) Edward D. Flinn: Welding Safely in Space, Aerospace America, 5(1998), pp.28-29.

7) K. NOGI, Y. AOKI, H. FUJII, K. NAKATA, S. KAIHARA: Weld Formation in Microgravity, Iron and Steel Institute of Japan International, 38, 2(1998), pp. 163-170.

8) K. NOGI, Y. AOKI, H. FUJII, K. NAKATA: BEHAVIOR OF BUBBLES IN WELD UNDER MICROGRAVITY, Acta Materialia, 46, 12(1998), pp.4405-4413.

9) 正箱信一郎、太田雅司、黄地尚義：Hollow Cathode Arc におけ るアーク柱の特性、溶接学会論文集、23, 2(2005), pp.270-275.

10）吹田義一、佃 芳行、寺嶋 昇、八田 崇、河野鉄平、猪熊力也、 川田賢司、他：航空機を使用した模擬宇宙環境下での GHTA 溶接実験、溶接学会論文集、18, 2(2000), pp.228-235.

11）吹田義一、十川弘樹、大原将広、他：模擬宇宙環境での宇宙 GHTA 溶接法による溶加ワイヤ供給を伴うアルミニウム管の 突合せ溶接実験、日本航空宇宙学会論文集、59, 689 (2011-6), 掲載予定。

12）吹田義一、黒川哲平、正箱信一郎、佐藤順子、莨谷英司、藤 澤正一郎、今川吉郎: 宇宙 LD 溶接法の提案、レーザ加工学誌、 9, 1(2002-2), pp.29-33.

13）吹田義一、田中健司、大谷雅人、正箱信一郎、他：宇宙半導 体レーザ溶接の宇宙適用を目指した光学部品の金属蒸着防止 技術、日本航空宇宙学会論文集, 58, 673(2010-2), pp.54-59.

14) Jeff Ding, Robert Carter et al.: Friction Stir Welding Flies High at NASA, Welding Journal 3(2006), pp.54-59.

15) 読売新聞（平成 4 年 5 月 29 日、13 版新全国版)、朝日新聞（平 成 4 年 5 月 29 日、13 版全国版)。

16) 吹田義一、佃 芳行、高木 隆、黄地尚義、増㴊興一：宇宙 空間での GTA 溶接に関する研究（第 1 報）、溶接学会論文集、 11, 3(1993), pp.423-427.

17) 吹田義一、山地直樹、寺嶋昇、佃 芳行 他: 小形ワイヤ 供給装置を使用した真空中でのステンレス鋼の宇宙 GHTA 溶 接、日本機械学会論文集 (C 編)、67,658(2001-6), pp.20442050.

18）吹田義一、増渕興一、寺嶋 昇、佃 芳行: 宇宙 GHTA 溶接 法による真空環境下での SUS304 鋼の溶接、日本機械学会論 文集（C 編）、64, 622(1998-6), pp.2304-2309.

19) 吹田義一、正箱信一郎、佐藤順子、黒川哲平、他: 宇宙ステーショ ン圧力での GHTA 溶接実験、溶接学会論文集、21, 1(2003), pp.33-38.

20) 吹田義一、高井大輔、杉山智志、他：ISS 軌道圧力での直 流高電圧方式による GHTA 起動実験、溶接学会論文集、21, 3(2003), pp.350-355.

21）吹田義一、松下和憲、寺嶋 昇、佃 芳行、増㴊興一：宇宙 GHTA 溶接法のタッチスタート技術による真空中でのアーク 起動現象、溶接学会論文集、24,1(2006), pp.26-31.

22）吹田義一、新池修平、江國友英、寺嶋 昇、佃芳行、今川吉郎: 真空中での宇宙 GHTA 溶接法によるアルミニウム合金の突合 せ溶接、日本航空宇宙学会論文集、52, 610(2004-11), pp.522527.

23）吹田義一、大原将広、十川弘樹、松下和憲、正箱信一郎、他： 航空機を使用した模擬宇宙環境での宇宙 GHTA 溶接法によ るアルミニウム管の溶接実験、溶接学会論文集、25,4(2007), pp.494-500.

24）吹田義一、佃芳行、寺嶋昇 他：真空中での GHTA 溶接に よるアルミニウム合金の溶接、溶接学会論文集、14, 4(1996)， pp.633-640.

25) 吹田義一、永井宏和、新池修平、他：アルミニウム合金の 真空中での GHTA 溶接現象、溶接学会論文集、22, 2(2004), pp.218-223.

26）例えば、水野、䇾田、坂口：アルミニウムとその合金の溶接、 産報出版 (1979)、西川、小坂、黄地：Hollow Cathode Arc の熱 源特性に関する研究 -アルミニウム合金の溶接への適用 - 、 高温学会誌、28(2002), pp.344-350.

27) Kaukler, W. F. and Workman, G. L.: Laser Welding in Space, Proceedings from the Conference "Welding in Space and the Construction of Space Vehicles by Welding", New Carrollton, Maryland (1991), pp.318-334.

28）吹田義一、莨谷英司、杉山智志、寺嶋 昇、佃 芳行、藤澤 正一郎、今川吉郎：宇宙空間での宇宙構造物の建造・修理を 対象にした宇宙レーザ溶接法の開発、日本航空宇宙学会論文 集、52(2004), pp.45-50.

29) 吹田義一、田辺心有、寺嶋 昇、佃 芳行、今川吉郎：宇宙 半導体レーザ溶接法による各種環境圧力でのステンレス鋼の 溶接現象、日本航空宇宙学会論文集、53, 620(2005-9), pp.426430.

30）三谷健太、吹田義一、相賀裕太郎、正箱信一郎、他：真空中 でのステンレス鋼の半導体レーザ突合せ溶接実験、第 24 回宇 宙利用シンポジウム、24(2008), pp.94-97. 